\title{
Interaction of Bulb Vernalization and Shoot Photoperiod on 'Nellie White' Easter Lily
}

\author{
John M. Dole ${ }^{1}$ and Harold F. Wilkins ${ }^{2}$ \\ Department of Horticulture and Landscape Architecture, Oklahoma State \\ University, Stillwater, OK 74078
}

Additional index words. Lilium longiflorum, long days, bulbs, flowering

\begin{abstract}
Easter lily (Lilium longiflorum Thunb. 'Nellie White') bulbs were exposed to 1, $2,3,4,5$, or 6 weeks of cold before shoot emergence; $0,1,2,3,4,5$, or 6 weeks of long days (LD) upon shoot emergence; or a combination of cold followed by LD: 1/5 (weeks cold/ weeks LD), 2/4,3/3,4/2, or 5/1. Experiments were repeated for three consecutive years. LD did not substitute equally for cold; at least 3 weeks of cold were required before LD treatments resulted in anthesis. Depending on the year, $100 \%$ of the plants flowered when treated with 3 to 6 weeks of cold alone or in combination with LD. Days to first flower anthesis from planting increased with decreasing weeks of cold in years 1 and 3 , but was similar for all treatments in year 2. Decreasing weeks of cold in combination with LD, however, decreased days to anthesis in years 1 and 2, but had no effect in year 3. Regardless of $L D$, days from emergence to visible bud increased with decreasing weeks of cold in all years, and days to emergence from placement in the greenhouse increased with decreasing cold in years 1 and 3, but not in year 2 . Increasing weeks of cold, regardless of LD, decreased leaf count, but had no effect on plant height. Flower count was unaffected by cold when combined with LD, but was significantly reduced by increasing weeks of cold.
\end{abstract}

Annually, Easter lily forcers face the difficulty of adjusting to variable Easter dates, variations in Easter lily bulb crops, and local weather conditions. Consequently, each year forcers must adapt to different unknown situations to produce a quality lily plant of proper height that flowers at the appropriate time. Long-standing recommendations suggest that Easter lily bulbs receive $1000 \mathrm{~h}$ (6 weeks) of cold treatment (vernalization), which results in rapid and uniform shoot emergence and flowering (De Hertogh and Wilkins, 1971a, $197 \mathrm{lb}$ ). This vernalization reduces the number of flowers and leaves produced, the number of days from planting to flower, the length of lower leaves, and plant height. Fewer flowers and shorter lower leaves are acceptable because forcing time is reduced.

Numerous authors have reported that exposure of newly emerging shoots to long days (LD) has a similar effect as bulb vernalization, i.e., decreasing days to flower and flower and leaf counts (Lin and Wilkins, 1973; Weiler and Langhans, 1968; Wilkins et al., 1968a,

\footnotetext{
Received for publication 26 Apr. 1993. Accepted for publication 23 Aug. 1993. Approved for publication by the director, Oklahoma Agricultural Experiment Station. This research was supported under project H-2119. We thank Royal Heins for his ideas and discussion, Randall Smith for assistance with data collection, and the Easter Lily Research Foundation, Brookings-Harbor, Ore., for bulb donations. The cost of publishing this paper was defrayed in part by the payment of page charges. Under posta regulations, this paper therefore must be hereby marked advertisement solely to indicate this fact. ${ }^{1}$ Assistant Professor.

${ }^{2}$ Visiting Professor, Current address: Ohio State Univ., 2001 Fyffe Court, Columbus, OH 432101096.
}

1968b). Most reports indicated that LD increase plant height (Kohl and Nelson, 1963; Smith and Langhans, 1962; Weiler and Langhans, 1968), but other reports noted that LD plants are shorter (Rob and Wilkins, 1977) or variable in height (Wilkins et al., 1968a, 1968b) compared with nonvernalized bulbs.

Roh and Wilkins ( 1973) suggested that LD could substitute equally for cold on a weekly basis. They theorized that flowering in Easter lily is controlled by two separate pathways. This information has been incorporated into Easter lily production through an "insurance policy," which consists of 1 to 3 weeks of LD after 6 weeks of bulb vernalization to ensure flower induction (Wilkins et al., 1970). One week normally is used on early emerging plants and 2 or 3 weeks on late-emerging plants, especially if Easter is early. However, Weiler and Langhans (1968, 1972) found that LD do not substitute equally for cold. The objective of this study was to reconsider whether LD could substitute equally for cold in producing high-quality, rapid-forcing Easter lily plants.

\section{Materials and Methods}

Year I-Minnesota. 'Nellie White' Easter lily bulbs (20-23 cm in circumference) were received in St. Paul, Minn., from a commercial supplier on 12 Oct. 1988 and held at $18 \pm 1.0 \mathrm{C}$. On 13 Oct., bulbs were dipped in a solution containing a commercial miticide and fungicides (Wilkins, 1988) and planted, one per pot, in $15-\mathrm{cm}$-diameter $(1720-\mathrm{ml})$ pots using an unamended 3 peat: 1 sand: 1 vermiculite (by volume) mixture. Planted bulbs were placed in a dark cooler at $18 \pm 1.0 \mathrm{C}$ for 26 days of additional root development.
On 7 Nov., bulbs were randomly assigned to one of the following treatments: $1,2,3,4,5$, or 6 weeks cold; $1,2,3,4,5$, or 6 weeks LD upon shoot emergence; 1 week cold followed by 5 weeks $\operatorname{LD}(1 / 5), 214,313,412$, or $5 / 1$; or 0 weeks cold or LD (control). Cold-treated bulbs were placed in a dark cooler at $5.5 \pm 1.0 \mathrm{C}$ for the respective durations and then moved to a glasshouse under natural daylengths $\left(45^{\circ} \mathrm{N}\right)$ [480 $\mu \mathrm{mol} \cdot \mathrm{m}^{-2} \cdot \mathrm{s}^{-1}$ photosynthetic active radiation (PAR)]. Plants were grown at $18 \pm 2.0 \mathrm{C}$, and LD treatments began when the shoot emerged. LD were achieved by a 4-h night interruption $(2200+200$ HR) with incandescent light (minimum of $11 \mu \mathrm{mol} \cdot \mathrm{m}^{-2} \cdot \mathrm{s}^{-1} \mathrm{PAR}$ at shoot tip). After LD, plants were grown under natural daylength.

Plant height (measured from the medium surface to the top of the tallest pedicel), and leaf and flower counts were recorded when the tepals of the first flower opened (anthesis). Dates of shoot emergence and visible bud were also recorded during forcing. The study was terminated on 30 Apr. 1989. A completely randomized design with five to 10 plants as individual replicates was used. Data were tested using trend analysis within the cold, LD, or cold and LD combined treatments (SAS Institute, Cary, N.C.). Paired $t$ tests were used to compare 6 weeks cold/O weeks LD (6/0) with all other treatments.

Year 2-Oklahoma. 'Nellie White' Easter lily bulbs (20-23 cm in circumference) were received in Stillwater, Okla., from Oregon (Pacific Bulb Growers Research and Development Station) on 28 Oct. 1989 and held at 18 \pm 0.5 c. On 30 Oct., bulbs were dipped in a solution containing a commercial miticide and fungicides (Wilkins, 1988) and planted, one per pot, in $15-\mathrm{cm}$-diameter $(1720-\mathrm{ml})$ pots using a commercial peat: perlite: vermiculite medium (Fafard Growing Mix No. 2; Conrad Fafard, Springfield, Mass.). Planted bulbs were placed in a dark cooler at $18 \pm 0.5 \mathrm{C}$ for 16 days of additional root development.

On 16 Nov., bulbs were randomly assigned to the same treatments listed under year 1 . Cold-treated bulbs were placed in a cooler at $5.5 \pm 0.5 \mathrm{C}$ for the respective durations and then moved to a fiberglass-reinforced, plasticcovered greenhouse under natural daylengths $\left(36^{\circ} \mathrm{N}\right)\left(560 \mu \mathrm{mol} \cdot \mathrm{m}^{-2} \cdot \mathrm{s}^{-1} \mathrm{PAR}\right)$. Plants were grown at 23.0/18.0C (day/night), and LD treatments began when the shoot emerged. Each treatment included eight to 12 bulbs and all other procedures were similar to year 1 . The experiment was terminated on 30 Apr. 1990.

Year 3-Oklahoma. Easter lilies were handled in the same manner as in year 2, except bulbs were planted 18 Oct. 1990 and placed in a dark cooler at $18 \pm 0.5 \mathrm{C}$ for 15 days of additional root development. The experiment was terminated on 30 Apr. 1991.

\section{Results}

Results are based on data from plants that flowered by 30 Apr. of each year, except for days to emergence, which was based on data from all plants (Table 1). At least 3 weeks of cold combined with LD were needed to induce 
Table 1. Influence of cold treatment and long days (LD) on Lilium longiflorum 'Nellie White'. Means are an average of data from plants that flowered by 30 Apr., except for days from placement in tie greenhouse to shoot emergence, which are from all five to 12 plants per treatment.

\begin{tabular}{|c|c|c|c|c|c|c|c|c|}
\hline \multirow[b]{2}{*}{$\begin{array}{l}\text { Weeks of } \\
\text { cold/LD }\end{array}$} & \multirow[b]{2}{*}{$\begin{array}{c}\text { Plants } \\
\text { flowering } \\
(\%)\end{array}$} & \multicolumn{4}{|c|}{ Days from } & \multirow[b]{2}{*}{$\begin{array}{c}\text { No. } \\
\text { teaves }\end{array}$} & \multirow[b]{2}{*}{$\begin{array}{c}\text { No. } \\
\text { flowers }\end{array}$} & \multirow[b]{2}{*}{$\begin{array}{c}\mathrm{Ht} \\
(\mathrm{cm})\end{array}$} \\
\hline & & $\begin{array}{l}\text { Placement in } \\
\text { greenhouse } \\
\text { to shoot } \\
\text { emergence }\end{array}$ & $\begin{array}{c}\text { Shoot } \\
\text { emergence to } \\
\text { visible bud }\end{array}$ & $\begin{array}{c}\text { Placement in } \\
\text { greenhouse to } \\
\text { first flower } \\
\text { anthesis }\end{array}$ & $\begin{array}{c}\text { Planting to } \\
\text { first flower } \\
\text { anthesis }\end{array}$ & & & \\
\hline \multicolumn{9}{|c|}{ Year $1-1988-89$} \\
\hline $6 / 0$. & 100 & 11 & 61 & 104 & 172 & 89.4 & 8.3 & 65.8 \\
\hline $5 / 0^{\circ}$ & 100 & $12^{\mathrm{Ns}}$ & $68^{\mathrm{Ns}}$ & $113^{\mathrm{Ns}}$ & $174^{\mathrm{Ns}}$ & $101.7^{\mathrm{Ns}}$ & $9.3^{\mathrm{Ns}}$ & $65.7^{\mathrm{vs}}$ \\
\hline $4 / 0$ & 100 & $11^{\mathrm{Ns}}$ & $79^{* *}$ & $122^{* *}$ & $176^{\mathrm{Ns}}$ & $121.0^{\mathrm{vs}}$ & $10.0^{\text {vs }}$ & $73.6^{\mathrm{vs}}$ \\
\hline $3 / 0$ & 100 & $11^{\mathrm{Ns}}$ & $90^{* *}$ & $135^{* *}$ & $182^{*}$ & $141.0^{* *}$ & $11.6^{* *}$ & $69.0^{\mathrm{Ns}}$ \\
\hline $2 / 0$ & 20 & $23^{*}$ & $107^{* *}$ & $147^{* *}$ & $187^{*}$ & $187.0^{* *}$ & $14.0^{* *}$ & $68.0^{\mathrm{ws}}$ \\
\hline $1 / 0$ & 0 & $18^{\text {Ns }}$ & $---^{y}$ & --- & --- & -.- & -.- & -- \\
\hline Significance & & $\mathrm{L}^{*}$ & $\mathrm{~L}^{* *}$ & $\mathrm{~L}^{*}$ & $\mathrm{~L}^{* *}$ & $\mathrm{~L}^{* *} \mathrm{Q}^{*}$ & $\mathrm{~L}^{* *}$ & NS \\
\hline $5 / 1$ & 100 & $6^{\mathrm{Ns}}$ & $70^{\mathrm{vs}}$ & $107^{\mathrm{Ns}}$ & $168^{\mathrm{Ns}}$ & $106.3^{\mathrm{Ns}}$ & $8.6^{\mathrm{ws}}$ & $65.6^{\mathrm{xs}}$ \\
\hline $4 / 2$ & 100 & $22^{*}$ & $57^{\mathrm{Ns}}$ & $112^{*}$ & $166^{\mathrm{Ns}}$ & $107.4^{\mathrm{Ns}}$ & $7.6^{\mathrm{Ns}}$ & $69.8^{\mathrm{Ns}}$ \\
\hline $3 / 3$ & 100 & $18^{\mathrm{Ns}}$ & $66^{\mathrm{ss}}$ & $116^{* *}$ & $163^{*}$ & $117.4^{\mathrm{NS}}$ & $8.4^{\mathrm{NS}}$ & $67.6^{\mathrm{NS}}$ \\
\hline $2 / 4$ & 100 & $15^{\mathrm{NS}}$ & $79^{* *}$ & $118^{* * *}$ & $158^{* *}$ & $115.4^{\mathrm{NS}}$ & $6.8^{\mathrm{Ns}}$ & $64.4^{\mathrm{Ns}}$ \\
\hline $1 / 5$ & 100 & $24^{*}$ & $67^{\mathrm{Ns}}$ & $126^{* *}$ & $159^{* *}$ & $122.2^{\mathrm{Ns}}$ & $8.8^{\mathrm{Ns}}$ & $73.8^{\mathrm{vs}}$ \\
\hline Significance & & $\mathrm{L}^{*}$ & NS & $\mathrm{L}^{* *}$ & $\mathrm{~L}^{*}$ & $\mathrm{~L}^{* *}$ & NS & NS \\
\hline $0 / 6$ & 10 & $11^{* *}$ & 65 & 158 & 184 & 97.0 & 9.0 & 54.0 \\
\hline $0 / 5$ & 0 & $11^{\mathrm{Ns}}$ & -.- & ... & --- & --. & -- & --- \\
\hline $0 / 4$ & 0 & $10^{\mathrm{Ns}}$ & -- & --- & --- & --- & -- & --- \\
\hline $0 / 3$ & 0 & $21^{\mathrm{Ns}}$ & --- & -.- & --- & 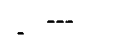 & --- & --- \\
\hline $0 / 2$ & 0 & $19^{*}$ & --- & ... & -.- & $-\ldots$ & --- & --- \\
\hline $0 / 1$ & 0 & $14^{\mathrm{Ns}}$ & --- & --- & --- & -.- & --- & --- \\
\hline $0 / 0$ & 0 & $16^{\mathrm{NS}}$ & $\cdots$ & $\cdots$ & -- & --- & -- & --- \\
\hline Significance & & Ns & & & & & & \\
\hline \multicolumn{9}{|c|}{ Year 2-1989-90 } \\
\hline $6 / 0$ & 100 & 5 & 62 & 101 & 159 & 71.2 & 5.0 & 38.9 \\
\hline $5 / 0$ & 100 & $4^{\mathrm{Ns}}$ & $65^{\mathrm{ss}}$ & $105^{\mathrm{Ns}}$ & $156^{\mathrm{NS}}$ & $77.0^{\mathrm{ws}}$ & $5.6^{\mathrm{Ns}}$ & $40.2^{\mathrm{vs}}$ \\
\hline $4 / 0$ & 100 & $12^{\mathrm{Ns}}$ & $75^{*}$ & $121^{* *}$ & $165^{\mathrm{Ns}}$ & $80.9^{\text {Ns }}$ & $5.3^{\mathrm{Ns}}$ & $34.2^{\mathrm{vs}}$ \\
\hline $3 / 0$ & 100 & $8^{\mathrm{NS}}$ & $81^{* *}$ & $121^{* *}$ & $158^{\mathrm{Ns}}$ & $86.5^{*}$ & $6.1^{\mathrm{Ns}}$ & $39.1^{\mathrm{Ns}}$ \\
\hline $2 / 0$ & 100 & $5^{\mathrm{Ns}}$ & $94^{* *}$ & $135^{* *}$ & $165^{\mathrm{Ns}}$ & $104.5^{* *}$ & $7.5^{* *}$ & $41.3^{\mathrm{ks}}$ \\
\hline $1 / 0$ & 50 & $8^{\mathrm{NS}}$ & $103^{* *}$ & $139^{* *}$ & $162^{\mathrm{NS}}$ & $105.2^{* *}$ & $7.2^{* *}$ & $37.4^{\mathrm{ss}}$ \\
\hline Significance & & NS & $\mathrm{L}^{* *}$ & $\mathbf{L}^{* *}$ & NS & $\mathrm{L}^{* *}$ & $\mathrm{~L}^{* *}$ & NS \\
\hline $5 / 1$ & 100 & $5^{\mathrm{Ns}}$ & $62^{\mathrm{Ns}}$ & $103^{\mathrm{Ns}}$ & $154^{\mathrm{Ns}}$ & $70.4^{\mathrm{Ns}}$ & $5.2^{\mathrm{Ns}}$ & $70.4^{\mathrm{Ns}}$ \\
\hline $4 / 2$ & 100 & $12^{\mathrm{Ns}}$ & $68^{\mathrm{Ns}}$ & $113^{*}$ & $157^{\mathrm{Ns}}$ & $74.4^{\mathrm{Ns}}$ & $5.6^{\mathrm{NS}}$ & $36.7^{\mathrm{ss}}$ \\
\hline $3 / 3$ & 100 & $9^{\mathrm{Ns}}$ & $70^{\mathrm{ws}}$ & $114^{* *}$ & $151^{\text {ss }}$ & $81.8^{\mathrm{Ns}}$ & $5.3^{\mathrm{Ns}}$ & $38.5^{\mathrm{Ns}}$ \\
\hline $2 / 4$ & 100 & $6^{\mathrm{NS}}$ & $75^{*}$ & $115^{* *}$ & $145^{* *}$ & $82.2^{\mathrm{Ns}}$ & $5.1^{\mathrm{NS}}$ & $39.1^{\mathrm{ss}}$ \\
\hline $1 / 5$ & 70 & $7^{\mathrm{Ns}}$ & $71^{\mathrm{Ns}}$ & $113^{*}$ & $136^{* *}$ & $76.5^{\mathrm{Ns}}$ & $5.7^{\mathrm{Ns}}$ & $36.6^{\mathrm{Ns}}$ \\
\hline Significance & & NS & $\mathrm{L}^{*}$ & $\mathrm{~L}^{*}$ & $\mathrm{~L}^{* *}$ & $\mathrm{~L}^{* *}$ & NS & NS \\
\hline $0 / 6$ & 67 & $6^{\mathrm{ns}}$ & $83^{* *}$ & $123^{* *}$ & $139^{* *}$ & $86.2^{*}$ & $6.2^{\mathrm{Ns}}$ & $36.7^{\mathrm{vs}}$ \\
\hline $0 / 5$ & 63 & $5^{\mathrm{Ns}}$ & $91^{* *}$ & $134^{* *}$ & $150^{\mathrm{Ns}}$ & $86.2^{*}$ & $7.0^{* *}$ & $35.2^{\mathrm{ss}}$ \\
\hline $0 / 4$ & 18 & $6^{\mathrm{NS}}$ & $97^{* *}$ & $137^{* *}$ & $153^{\mathrm{NS}}$ & $98.5^{*}$ & $8.5^{* *}$ & $28.0^{* *}$ \\
\hline $0 / 3$ & 0 & $3^{\mathrm{vs}}$ & --- & -.. & --- & -.. & --- & --- \\
\hline $0 / 2$ & 0 & $7^{\mathrm{Ns}}$ & --- & --. & --- & --- & $\cdots$ & --- \\
\hline $0 / 1$ & 0 & $5^{\mathrm{Ns}}$ & --- & ... & --- & -.- & $\ldots$ & $\ldots$ \\
\hline $0 / 0$ & 0 & $6^{\mathrm{Ns}}$ & -.. & -.- & ... & --- & --- & --- \\
\hline Significance & & NS & NS & NS & NS & Ns & NS & $L^{*}$ \\
\hline \multicolumn{9}{|c|}{ Year 3-1990-91 } \\
\hline $6 / 0$ & 100 & 20 & 49 & 102 & 159 & 76.8 & 5.3 & 30.9 \\
\hline $5 / 0$ & 100 & $19^{\text {Ns }}$ & $60^{*}$ & $111^{* *}$ & $161^{\mathrm{NS}}$ & $84.0^{\mathrm{ws}}$ & $5.3^{\mathrm{Ns}}$ & $33.4^{\mathrm{Ns}}$ \\
\hline $4 / 0$ & 100 & $20^{\text {Ns }}$ & $64^{* *}$ & $119^{* *}$ & $162^{\mathrm{Ns}}$ & $96.7^{* *}$ & $6.1^{* *}$ & $33.2^{\mathrm{vs}}$ \\
\hline $3 / 0$ & 83 & $20^{\mathrm{Ns}}$ & $80^{* *}$ & $135^{* *}$ & $171^{* *}$ & $108.2^{* *}$ & $7.2^{* *}$ & $33.7^{\mathrm{Ns}}$ \\
\hline $2 / 0$ & 0 & $26^{\mathrm{NS}}$ & -- & --- & -- & -- & --- & --- \\
\hline $1 / 0$ & 0 & $23^{\mathrm{Ns}}$ & --- & --- & -.- & --- & --. & --. \\
\hline Significance & & $\mathrm{L}^{* *}$ & $\mathrm{~L}^{* *}$ & $L^{* *} Q^{* *}$ & $\mathrm{~L}^{* *} \mathrm{Q}^{* *}$ & $\mathrm{~L}^{* *}$ & $\mathrm{~L}^{* *}$ & NS \\
\hline $5 / 1$ & 100 & $15^{\mathrm{Ns}}$ & $58^{*}$ & $107^{*}$ & $157^{\mathrm{Ns}}$ & $83.4^{\mathrm{Ns}}$ & $5.5^{\mathrm{Ns}}$ & $36.1^{\mathrm{Ns}}$ \\
\hline $4 / 2$ & 100 & $21^{\mathrm{Ns}}$ & $57^{\mathrm{Ns}}$ & $117^{* *}$ & $160^{N s}$ & $96.8^{* *}$ & $5.7^{\mathrm{Ns}}$ & $36.5^{*}$ \\
\hline $3 / 3$ & 100 & $20^{\mathrm{Ns}}$ & $65^{k *}$ & $120^{* *}$ & $156^{\mathrm{Ns}}$ & $95.8^{* *}$ & $5.4^{\mathrm{Ns}}$ & $34.4^{\mathrm{ws}}$ \\
\hline $2 / 4$ & 78 & $28^{\mathrm{Ns}}$ & $70^{* *}$ & $132^{* *}$ & $161^{\mathrm{Ns}}$ & $104.4^{* *}$ & $7.0^{*}$ & $38.7^{*}$ \\
\hline $1 / 5$ & 0 & $27^{\mathrm{ss}}$ & --- & --- & --- & --- & --- & --- \\
\hline Significance & & $\mathrm{L}^{* *}$ & $\mathbf{L}^{* *}$ & $\mathrm{~L}^{* *}$ & NS & $\mathrm{L}^{* *}$ & NS & NS \\
\hline $0 / 6$ & 0 & $55^{* *}$ & -- & --. & -- &.-- & -- & -- \\
\hline $0 / 5$ & 0 & $45^{* *}$ & $\therefore-$ & --- & $\cdots$ & --- & --- & --- \\
\hline $0 / 4$ & 0 & $65^{* *}$ & --. & -.- & --- & --- & --. & --- \\
\hline $0 / 3$ & 0 & $58^{* *}$ & --- & --- & --- & --- & --- & --- \\
\hline $0 / 2$ & 0 & $55^{* *}$ & --- & -.- & -- & --- & --- & --- \\
\hline $0 / 1$ & 0 & $54^{* *}$ & -- & -- & -- & --- & --- & --- \\
\hline & 0 & $56^{* *}$ & $\ldots$ & --- & --- & --- & -.- & --- \\
\hline Significance & & NS & & & & & & \\
\hline
\end{tabular}

${ }^{2}$ Planting dates: year 1, 13 Oct. 1988; year 2,30 Oct. 1989; year 3, 18 Oct. 1990.

'Plants did not reach anthesis by $30 \mathrm{Apr}$.

$*,{ }^{* *}{ }^{\text {NS }}$ Significant at $P \leq 0.05$ or 0.01 or nonsignificant, respectively, as compared to treatment $6 / 0$ or from linear (L) or quadratic (Q) response, 
flowering in all years (Table 1). Only one plant flowered in year $1,67 \%$ in year 2, and no LDonly plants flowered in year 3 . The plants that flowered under 6 weeks of LD in year 2 had more leaves and required more days from emergence to visible bud, from placement in greenhouse to anthesis, and from visible bud to anthesis (data not presented) than plants grown with 6 weeks of cold.

Weiler and Langhans $(1968,1972)$ also noted that LD-only plants did not flower and that 3 to 4 weeks of cold combined with LD applied until anthesis were required to induce $100 \%$ flowering. They grew the plants at a $21 \mathrm{C}$ minimum. In contrast, Roh and Wilkins ( 1973) conducted studies at a $15.6 \mathrm{C}$ night minimum and found that LD could substitute equally for cold on a weekly basis. In our studies, the night minimum temperatures were regularly $>18 \mathrm{C}$. In year 2 , the night temperature during one 4-day period (22-25 Dec. 1989) ranged from 10 to $16 \mathrm{C}$, which may have vernalized the plants enough to allow $18 \%, 63 \%$, and $67 \%$ of plants receiving 4,5 , or 6 weeks of LD, respectively, to flower (Table 1). Roh and Wilkins (1973) used night forcing at 15.6C, which provided an unplanned cold treatment (Hill and Durkin, 1968; Roberts and Moeller, 197 1). Night forcing was at $15.6 \mathrm{C}$ in other studies, which also found that LD could induce flowering (Rob and Wilkins, 1977; Wilkins et al., 1968a, 1968b). Lin and Wilkins (1973) also noted that LD alone were not effective when forcing temperatures were 21C. Differences in bulb maturity, bulb weight, and temperature in the production fields also may have caused the variation between years in Easter lily response to LD and cold (Roberts et al., 1978, 1985).

In all years, 5/1 plants reached anthesis from planting in a similar number of days as $6 / 0$ plants (Table 1 ). In year 3 , however, the $5 / 1$ plants took significantly more days from emergence to visible bud and from placement in greenhouse to anthesis than the $6 / 0$ plants. In years 1 and 2, 6/0 plants placed in the greenhouse reached anthesis before the $5 / 1$ plants, but the differences were not significant $(P \leq 0.05)$. Variations in average daily temperature probably account for the different responses between years. Plants in $4 / 2$ and $3 / 3$ reached anthesis from planting at the same time or sooner and had similar heights and flower counts as $6 / 0$ plants in all years. However, the $4 / 2$ and $3 / 3$ plants required a similar number of days, or more, from placement in the greenhouse to shoot emergence and anthesis and from shoot emergence to visible buds than $6 / 0$ plants. The $4 / 2$ and $3 / 3$ plants also had the same number, or more, leaves than the $6 / 0$ plants. Roh and Wilkins (1973) found that decreasing cold exposure combined with an increasing number of LD increased leaf count, decreased days from planting to anthesis, and had no effect on height and flower count Although Weiler and Langhans $(1968,1972)$ applied LD from the end of the cold treatment until flowering, they also found that decreasing cold increased leaf count and the percentage of flowering plants, and decreased days from planting to anthesis.
While plant height was not influenced by combinations of cold and LD in our studies, Weiler and Langhans (1968) noted that height increased with decreasing cold, which was due to the continual application of LD during forcing (Smith and Langhans, 1962; Weiler and Langhans, 1968).

Easter lily response to cold alone was similar to that from earlier work (De Hertogh and Wilkins, 197 la, 197 lb; Miller and Kiplinger, 1966; Roh and Wilkins, 1973): increasing cold exposure decreased leaf and flower counts and number of days from emergence to visible bud and from planting or placement in the greenhouse to anthesis (Table 1). In years 1 and 3, as with previous work, days to emergence decreased linearly with increasing weeks of cold (Rob and Wilkins, 1973), but was not influenced by cold in year 2 . The difference between years may have been due to rapid shoot emergence in year 2; the majority of shoots emerged in fewer than 10 days, resulting in no differences between treatments. In the other two years, however, most shoots emerged after $\geq 10$ days. Year 2 bulbs may have been more mature than those in years 1 and 3. Roberts et al. (1978) noted that shoots from heavier (more mature) bulbs emerged quicker than those from lighter (more immature) bulbs. Plant height was not influenced by weeks of cold exposure, which corresponds to results obtained by Merritt (1963).

As with previous reports (Rob and Wilkins, 1977; Weiler and Langhans, 1968; Wilkins et al., 1968a, 1968b), increasing weeks of LD decreased days to anthesis, days from emergence to visible bud, and leaf and flower counts, although the trends were not significant $(P \leq 0.05)$, probably because of the low percentage of flowering plants (Table 1). Plant height increased significantly with increasing weeks of LD, which is similar to Smith and Langhans' (1962) and Weiler and Langhans' (1968) results.

In summary, LD did not substitute equally for cold in Easter lily flowering; at least 3 weeks of cold combined with LD were required for $100 \%$ flowering (Table 1). Plants receiving 3,4 , or 5 weeks of cold in combination with 3,2 , or 1 week of $\mathrm{LD}$, respectively, flowered at the same time or slightly earlier than plants receiving 6 weeks of cold. By using LD in combination with cold, growers could free up cooler space, but more time in the greenhouse would be required because of increasing days from emergence to visible bud with decreasing weeks of cold. Days from placement in the greenhouse to emergence and from visible bud to anthesis (data not presented) were not influenced by cold.

Also important to consider is that greenhouse temperatures $<18 \mathrm{C}$ might inadvertently provide temperatures low enough for flower induction. This information may be of negligible importance to growers, because anthesis would be delayed even though the low temperatures might enhance flower induction relative to plants grown with higher temperatures. However, researchers should be aware of the effects of night forcing temperatures on experiments.

\section{Literature Cited}

De Hertogh, A.A. and H.F. Wilkins. 1971a. The forcing of northwest-grown 'Ace' and 'Nellie White' lilies. Part 1. Florist's Rev. 149(3857):2931

De Hertogh, A.A. and H.F. Wilkins. 1971b. The forcing of northwest-grown 'Ace' and 'Nellie White' lilies. Part 2. Florist's Rev. 149(3858):57, 104-111.

Hill, L.L. and D.J. Durkin. 1968. Vernalization of the growing Easter lily. HortScience 3:277.

Kohl, H.C. and R.L. Nelson. 1963. Daylength and light intensity as independent factors in determining height of Easter lilies. Proc. Amer. Soc. Hort, Sci. 83:808-810.

Lin, W.C, and H.F. Wilkins. 1973. The influence of temperature on photoperiodic responses of Lilium longiflorum Thunb. cv. Nellie White. Florist's Rev. 153(3965):24-26.

Merritt, R.H. 1963. Vegetative and floral development of plants resulting from differential precooking of planted Croft lily bulbs. Proc. Amer. Soc. Hort. Sci. 82:517-525.

Miller, R.O. and D.C. Kiplinger. 1966. Interaction of temperature and time of vernatization on northwest Easter lilies. Proc. Amer. Soc. Hort. Sci. 88:635-645

Roberts, A.N., J.L. Green, and F.W. Moeller. 1978. Lily bulb harvest maturity indices predict forcing response. J. Amer. Soc. Hort. Sci. 103:827-833.

Roberts, A.N. and F.W. Moeller. 1971. Vegetative and flowering responses of Lilium longiflorum Thunb. cultivars to cold and long day treatment as related to bulb maturity. Acts Hort. 23:58-65.

Roberts, A. N., J.R. Stand, Y.T. Wang, W.R. McCorkle, L.J. Riddle, and R.W. Moeller. 1985. Easter lily growth and development. Oregon Agr. Expt. Sta. Tech. Bul. 148.

Rob, S.M. and H.F. Wilkins. 1973. The influence and substitution of long days for cold treatments on growth and flowering of Easter lilies (Lilium longiflorm Thunb. 'Georgia' and 'Nellie White'). Florist's Rev. 153(3960): 19-21, 60-63.

Rob, S.M. and H.F. Wilkins. 1977. Temperature and photoperiod effect on flower numbers in Lilium longiflorum Thunb. J. Amer. Soc. Hort. Sci. 102:235-242.

Smith, D.R. and R.W. Langhans. 1962. The influence of photoperiod on the growth and flowering of Easter lily (Lilium longiflorum Thunb. var Croft). Proc. Amer. Soc. Hort. Sci. 80:599-404.

Weiler, T.C. and R.W. Langhans. 1968. Effect of photoperiod on the vernalization requirement of Lilium longiflorum(Thunb.) cv Ace. Proc. Amer. Soc. Hort. Sci. 93:630-634.

Weiler, T.C. and R.W. Langhans. 1972. Growth and flowering responses of Lilium longiflorum Thunb. 'Ace' to different daylengths. J. Amer. Soc. Hort. Sci. 97:176-177.

Wilkins, H.F. 1988. University of Minnesota's step-by-step success 1988-1 989 lily forcing season. Minn. State Flor. Bul. 37:6-7.

Wilkins, H. F., W.E. Waters, and R.E. Widmer 1968a. Influence of temperature and photoperiod on growth and flowering of Easter lilies (Lilium longiflorum Thunb. 'Georgia', 'Ace' and 'Nellie White'). Proc. Amer. Soc. Hort. Sci. 93:640-649.

Wilkins, H. F., R.E. Widmer, and W.E. Waters. $1968 \mathrm{~b}$. The influence of carbon dioxide, photoperiod and temperature on growth and flowering of Easter lilies (Lilium longiflorum Thunb. 'Ace' and 'Nellie White'). Proc. Amer. Soc. Hort. Sci. 93:650-654.

Wilkins, H. F., R.E. Widmer, and W.E. Waters 1970. An insurance policy: Lighting lilies at shoot emergence will overcome inadequate bulb precooking. Florist's Rev. 147(3806):60-61, 109. 